\section{Successful Philanthropy}

By choosing to devote the bulk of its funds to the problems of population control, the conquest of hunger, equal opportunity and university development, the Rockefeller Foundation, as its president, J. G. Harrar, says in his introduction to the president's review and annual report for 1967 , was facing a series of calculated risks: the risk of being in error, of outright failure and of the resentment and suspicion of the recipients of charity. But, as the report shows, the foundation's faith in its policies was more than justified.

New strains of wheat developed in Mexico at the International Maize and Wheat Improvement Centre (CIMMYT), which is almost entirely supported by the Rockefeller and Ford Foundations, are revolutionizing agricultural production in India, Pakistan and Turkey as they have in Mexico. India and Pakistan are expecting record wheat harvests this year (see Nature, 218,$713 ; 1968$ ) and in the past eighteen months India, Pakistan and Turkey have respectively purchased 18,000 tons, 42,000 tons and 22,000 tons of seed wheat from Mexico. Yields have increased from 1.2 tons per hectare to 4 or even 8 tons per hectare.

The rice strain 1188 , developed at the International Rice Research Institute at Los Banos in the Philippines and released for the first time in June 1966 ready for the wet season that year, is likely to have as great an impact on rice production throughout S.E. Asia as the CIMMY'T wheat strains have had on wheat production, and at IRRI scientists are being trained to carry on rice research in their own countries. The foundation is also financing research into sorghum in India, potatoes in Mexico and, encouraged no doubt by the outstanding successes of CIMMYT and IRRI, it is planning two new institutes. In cooperation with the Columbian government the International Centre of Tropical Agriculture at Palmira was inaugurated last year and plans for a second tropical agriculture centre at Ibadan in Nigeria have almost reached the building stage. The results of the foundation's investment in plant breeding are perhaps the outstanding example of how relatively trivial sums of money can totally change the agricultural prospects of continents.

The other side of the coin is, of course, control of the world population and, apart from research grants to individual scientists, the foundation channels its funds through them. It employs no field workers but in January gave the Population Council $\$ 3$ million for the programmes of its technical division.

In the past, perhaps the most controversial of the Rockefeller Foundation's activities has been its support of Negro universities, especially in the south. Aid to these universities can be criticized on the ground that it helps perpetuate segregation, and although President Harrar defends it in his annual review most of the grants made in 1967 to American universities went to desegregated institutions outside the south. It will be surprising if "towards equal opportunity for all" does not prove to be a much more difficult programme than "towards the conquest of hunger". Apart from trying to provide opportunities for higher education to American Negroes and other minorities the foundation has continued to support heavily university development overseas. In 1967 it spent $\$ 1.8$ million on centres in South America, Africa and Asia that were selected in 1963 for long term support.
Parliament in Britain

$$
\text { by our Parliamentary Correspondent }
$$

\section{Bladder Cancer}

Dr Shirley Summerskill asked what was being done to encourage those who had worked in contact with naphthylamine to be screened for bladder cancer. Mr E. Fernyhough, Under Secretary for Employment and Productivity, said that the Carcinogenic Substances Regulations of 1967 required all those working in factories exposed to alpha or beta-naphthylamine to be screened for bladder cancer. The regulations in fact forbid the production and use of beta-naphthylamine. But Mr Fernyhough agreed that it was difficult to persuade those who no longer worked in situations of risk to present themselves for screening. Dr Summerskill suggested that there were several hundred thousand such people; Mr Fernyhough said that 43,000 have been contacted, but only 2,500 had come forward for screening. (Oral answer, July 1.)

\section{Synthetic Protein}

MR J. H. OsBorNe asked about international collaboration on the production of synthetic proteins and carbohydrates. Mrs Shirley Williams, for the Department of Education and Science, said that she had arranged no international collaboration, but that a good deal of work was going on, both in Britain and abroad. Various ARC units were at work on sources of protein, and the use of compounds such as urea as replacements for protein. Commercial firms and the National Agricultural Advisory Service were also helping, and internationally the Economic and Social Council of the UN was acting as an information centre. (Written answer, July 1.)

Industrial Archaeology

Mr R. Mellish, for the Ministry of Public Building and Works, said that the amount of money spent by his department on industrial archaeology had been $£ 6,125$ in $1965-66, £ 4,127$ in $1966-67$, and $£ 14,570$ in 1967-68. (Written answer, July 2.)

\section{Chapelcross}

Dr Jeremy Bray, for the Ministry of Technology, gave the costs of the breakdown of the Atomic Energy Authority's reactor at Chapelcross. The cost of repairs had been about $£ 150,000$ and the loss of revenue about $\mathfrak{f 1}$ million. But the reactor was likely to be out of action for some months, and the final cost could not yet be estimated. (Written answer, July 3.)

\section{Antibiotics on Farms}

The members of the Swann Committee on Antibiotics in Animal Husbandry are Dr K. L. Blaxter, director of the Rowett Research Institute, Aberdeen; $\mathrm{Mr}$ H. I. Field, director of Veterinary Laboratories and Veterinary Investigation Service, Ministry of Agriculture, Fisheries and Food, Weybridge; Dr J. W. Howie, director of the Public Health Laboratory Service; Professor I. A. M. Lucas, professor of animal nutrition, University of North Wales; Dr F. L. M. Millar, medical officer of health, Birmingham; Professor J. C. Murdoch, director of the Agricultural Research Institute of Northern Ireland; Mr J. H. Parsons, veterinary practitioner, Trowbridge; Professor E. G. White, professor of veterinary preventive medicine, University of Liverpool. The chairman is Professor M. M. Swann of the University of Edinburgh. (Writter. answer, July 5.) 